\title{
Effects of Boric Acid and Humate Supplementation on Performance and Egg Quality Parameters of Laying Hens
}

\section{Euthor(s)}

Hakan $\mathrm{KB}^{\mathrm{a}^{*}}$

Gultekin $Y^{b}$

Ozge $S^{b}$

a Faculty of Veterinary Medicine, Department of Animal Nutrition and Nutritional Diseases, University of Adnan Menderes, 09016 Isikli, Aydın, Turkey

${ }^{b}$ Faculty of Veterinary Medicine, Department of Animal Nutrition and Nutritional Diseases, University of Ankara, 06110, Diskapi, Ankara, Turkey

\section{-Mail Adress}

* Mail Adress (Corresponding author): KOKSAL, Bekir Hakan, Assist. Prof. Department of Animal Nutrition and Nutritional Diseases, Faculty of Veterinary Medicine, University of Adnan Menderes, 09016, Isikli-Aydin/ TURKEY.

E-mail: bhakankoksal@gmail.com

\section{EKeywords}

Boron, egg production and quality, humic substance, performance.

\section{ABSTRACT}

In this study, the effects of boric acid and humate supplementation into hen diets on egg production and quality parameters and blood cholesterol levels were examined. For this aim, totally 160, 40 weeks of age, Hyline-White 98 layers were randomly divided into control and 3 treatment groups each containing 40 birds and 10 replicates (each with 4 birds). There was no boric acid or humate supplementation to control group diets (basal diet) where as treatment groups were supplemented with (basal diet plus) 90 ppm boric acid or $1 \mathrm{~g} / \mathrm{kg}$ humate, or combination of these two feed additives, respectively. The experimental period lasted in 14 weeks. End of the trial there were no significant effects of dietary boric acid and humate inclusion on feed intake, egg weights and yields, egg quality parameters (shell thickness, breaking strength, and shape index) compared with control. But feed conversion ratio for hens which were supplemented with humate showed negative results while combination humate and boric acid were showed positive result compare with control $(p<0.05)$. It was also determined that there were no effects of treatments on blood cholesterol levels. As a result, since hens which were fed with basal diet plus boric acid and humate combination showed better feed conversion ratio, these feed additives combination can added diets without any adverse effect for laying hens.

\section{INTRODUCTION}

In layer hen industry, egg quality and production are the most important economic facts. In this context age-related decline of egg production and shell quality are major factors affecting the profitability (Nys, 1999). Prevent from these age-related problems, producers add mineral premixes or feed additives into layer diets (Ergin, 2009). Even though usage of humate/humic substances in laying hen diets like as feed additive is already known subject addition of boron/boric acids into rations is substantially new issue in this area.

Boron (B) is the chemical element with atomic number 5 and the chemical symbol $B$ (Nist, 2011) and it is an essential element for animal and humans as well as plants (WHO, 1998). It is combined with oxygen and other elements in compounds called borates which are widely found in nature, and are present in oceans, sedimentary rocks, coal and some soils. Boron is primarily obtained from boron mines, located in arid regions of Turkey (IPCS, 1998). World boron reserves are $64 \%$ in Turkey, $11 \%$ in Russia and 9\% in USA (Kilic, 2008). It is accepted that boron has functions in mineral metabolism, lipid metabolism, immune response, endocrine system and brain (Hunt, 1989; Hegsted et al., 1991; Dupre et al., 1994; Yesilbag, 2008). However, the biochemical function of $B$ is not fully understood in animals (WHO, 1996). Kurtoglu et al. (2002) determined that boron provided significant improvements on

\footnotetext{
1 Some results of this "Trail" has been presented in V. National Animal Nutrition Congress, at 2009, Tekirdag, Turkey.
}

Submitted: August/2011 Approved: April/2012 
serum calcium ( $\mathrm{Ca}$ ) levels and damaged egg ratio but no significant difference between the controls and the boron supplemented groups (50, 100, 150, 200 and 250 ppm) about feed consumption, feed conversion ratio, egg production, body weight and egg weight. Eren et al. (2004) found that similar findings like as Wilson \& Ruszler (1998) about B addition to laying hen diets at level of $400 \mathrm{ppm}$ resulted negative values of live weight, feed consumption and egg productivity parameters. Wilson \& Ruszler (1998) also noticed that 200 ppm B addition resulted better performance and bone strength findings compare with other treatment groups in laying hens in their trial.

Humic substances/humates (HS) are compounds arising from the physical, chemical and microbiological transformation (humification) of bio molecules from soil. Humic acids, fulvic acids and humin are three main components of HS according to their solubility and humic acids are the most well known group of them. Properties of humic acids have attracted the attention of many investigators recent years (Yildiz et al., 2009). Previously HS were used as a part of replacement therapy for digestive system disorders such as malnutrition and diarrhea (Kuhnert et al., 1989; 1991) later it has been investigated that their effects on performance parameters in dairy cattle (Hobbs, 1995), broiler (Aksu et al., 2005), quail (Yalcin et al., 2005) and laying hens (Kucukersan et al., 2004 and 2005). Yoruk et al. (2004) reported that supplementation of humate into the diet at level of 0.1 and $0.2 \%$ during the late laying period improved feed conversion ratio, increased egg production and reduced mortality. Moreover, Kucukersan et al. (2005) reported that addition different amount of humate (30 and $60 \mathrm{ppm}$ ) into layer diets showed significant results about egg production, egg weight and feed efficiency $(p<0.05)$. However, previous studies (Kucukersan et al., 2004; Hayirli et al., 2005) showed that egg production and egg shell quality parameters were not affected by dietary addition of humate in layers.

The aim of this research was to determine the effect of boric acid and humate addition in the diet on performance, egg quality parameters and blood cholesterol levels of laying hens.

\section{MATERIAL AND METHODS}

\section{Layers, experimental design and diet}

This research was carried out on 40 wks old, totally 160 laying hens (Hyline White ${ }^{\circledR}$ 98). The birds were randomly divided into 4 groups according to the dietary regimen and each group was constituted by 10 subgroups of 4 birds. The experimental protocol was approved by the local Ethics Committee of the Ankara University.

In the control group, chickens were fed with basal standard diets based on corn and soybean meal, more specifically with a layer diets $[16.5 \%$ crude proteins $(\mathrm{CP})$ and $2750 \mathrm{kcal} / \mathrm{kg}$ metabolisable energy (ME)] for all experiment period (for 14 wks, Table 1) with recommendations of the National Research Council (1994) for layers. Birds from the groups 2 and 3 received standard diets supplemented with $1 \%$ boric acid (BA) (90 ppm) or humate $(\mathrm{H})(1 \mathrm{~g} / \mathrm{kg})$ respectively whereas in the group 4, hens were supplemented with both of these additives (HBA) $(90 \mathrm{ppm}$ boric acid plus $1 \mathrm{~g} / \mathrm{kg}$ humate). Feeds were analyzed for crude protein, calcium, and total phosphorous according to the reference methods (AOAC, 2000). During the experimentfeed and waterwere given to hensad libitum.

Table 1. Basal diet composition and calculated \& analyzed results of feed ingredient for laying hens diets.

\begin{tabular}{|c|c|}
\hline Ingredients & Percentage \\
\hline Corn & 40.00 \\
\hline Wheat & 21.37 \\
\hline Soybean meal & 15.20 \\
\hline Sun flower meal & 5.00 \\
\hline Soybean, full fat & 6.00 \\
\hline Oil & 1.69 \\
\hline Limestone & 8.28 \\
\hline Dicalcium phosphate & 1.60 \\
\hline Common salt & 0.35 \\
\hline Vitamin and mineral premix1 & 0.15 \\
\hline DL-Methionine & 0.25 \\
\hline DL-Treonine & 0.06 \\
\hline Antioxidant & 0.05 \\
\hline Total & 100.00 \\
\hline \multicolumn{2}{|l|}{ Calculated Results (TSE, 1991) } \\
\hline Crude protein (\%) & 16.50 \\
\hline ME (kcal/kg) & 2,750 \\
\hline \multicolumn{2}{|l|}{ Analyzed Results } \\
\hline Crude protein (\%) & 16.40 \\
\hline ME (kcal/kg) & 2697 \\
\hline Calcium (\%) & 3.69 \\
\hline Phosphor (\%) & 0.55 \\
\hline \multicolumn{2}{|c|}{ 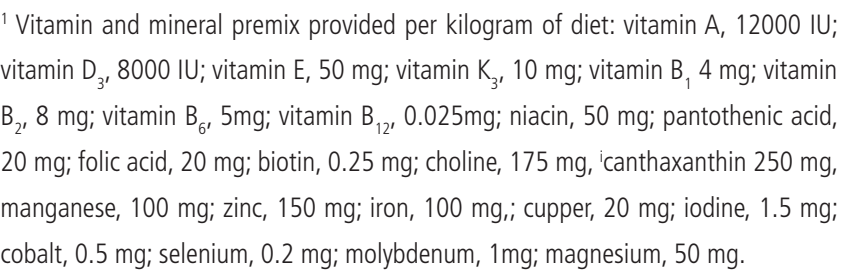 } \\
\hline
\end{tabular}


Table 2 - Some performance parameters of laying hens for weekly (Mean \pm SE)

\begin{tabular}{|c|c|c|c|c|c|c|}
\hline \multicolumn{7}{|c|}{ Experiment Groups } \\
\hline & Weeks & C (Control) & $\mathrm{H}$ (1 g/kg Humate) & BA (90 mg/kg Boric Acid) & HBA (90 ppm BA plus $1 \mathrm{~g} / \mathrm{kg} \mathrm{H}$ ) & $\mathrm{P}$ \\
\hline \multirow{8}{*}{ 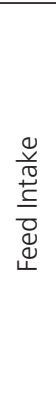 } & $1-2$ & $112.36 \pm 1.60$ & $113.11 \pm 1.49$ & $109.24 \pm 0.97$ & $110.59 \pm 2.35$ & 0.369 \\
\hline & $3-4$ & $105.31 \pm 1.52$ & $107.49 \pm 1.42$ & $105.36 \pm 1.38$ & $104.96 \pm 1.55$ & 0.608 \\
\hline & $5-6$ & $106.21 \mathrm{a} \pm 2.26$ & $106.27 a \pm 1.62$ & $103.07 a b \pm 0.95$ & $99.05 b \pm 1.13$ & $0.010 * *$ \\
\hline & $7-8$ & $104.46 \pm 1.97$ & $103.61 \pm 1.74$ & $101.74 \pm 1.50$ & $103.83 \pm 1.27$ & 0.679 \\
\hline & $9-10$ & $98.06 \pm 2.18$ & $96.39 \pm 2.21$ & $96.04 \pm 1.86$ & $95.65 \pm 1.72$ & 0.836 \\
\hline & $11-12$ & $90.83 \pm 2.06$ & $90.46 \pm 2.83$ & $91.39 \pm 1.53$ & $92.65 \pm 2.10$ & 0.900 \\
\hline & $12-14$ & $80.47 \pm 2.61$ & $77.63 \pm 2.53$ & $79.42 \pm 1.05$ & $78.81 \pm 2.35$ & 0.836 \\
\hline & $1-14$ & $99.68 \pm 1.63$ & $99.28 \pm 1.55$ & $99.04 \pm 0.93$ & $97.59 \pm 1.38$ & 0.689 \\
\hline \multirow{8}{*}{ 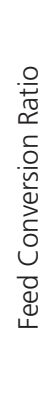 } & $1-2$ & $1.95 \pm 0.04$ & $2.05 \pm 0.07$ & $1.89 \pm 0.04$ & $1.86 \pm 0.04$ & 0.056 \\
\hline & $3-4$ & $1.98 \pm 0.08$ & $2.14 \pm 0.09$ & $1.90 \pm 0.04$ & $1.99 \pm 0.04$ & 0.093 \\
\hline & $5-6$ & $2.01 b \pm 0.05$ & $2.15 a \pm 0.05$ & $1.88 \mathrm{c} \pm 0.02$ & $1.80 c \pm 0.05$ & $0.000 * * *$ \\
\hline & $7-8$ & $2.10 \pm 0.07$ & $2.08 \pm 0.05$ & $2.01 \pm 0.04$ & $2.03 \pm 0.04$ & 0.534 \\
\hline & $9-10$ & $1.91 \pm 0.07$ & $1.93 \pm 0.04$ & $1.95 \pm 0.05$ & $1.90 \pm 0.04$ & 0.907 \\
\hline & $11-12$ & $1.94 \pm 0.06$ & $2.00 \pm 0.06$ & $1.94 \pm 0.04$ & $1.96 \pm 0.04$ & 0.850 \\
\hline & $12-14$ & $1.90 \pm 0.09$ & $1.86 \pm 0.08$ & $1.89 \pm 0.06$ & $1.76 \pm 0.08$ & 0.597 \\
\hline & $1-14$ & $1.97 a b \pm 0.05$ & $2.03 a \pm 0.04$ & $1.92 \mathrm{ab} \pm 0.27$ & $1.88 b \pm 0.02$ & $0.044^{*}$ \\
\hline \multirow{8}{*}{ 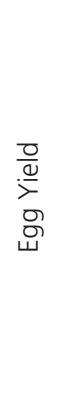 } & $1-2$ & $92.00 \pm 1.90$ & $91.29 \pm 2.72$ & $95.00 \pm 1.49$ & $97.14 \pm 1.20$ & 0.130 \\
\hline & $3-4$ & $86.29 \pm 2.06$ & $85.00 \pm 2.11$ & $89.57 \pm 1.88$ & $85.86 \pm 1.59$ & 0.367 \\
\hline & $5-6$ & $86.57 a b \pm 2.16$ & $83.43 b \pm 1.77$ & $89.71 a \pm 1.27$ & $89.00 \mathrm{a} \pm 0.80$ & $0.035^{*}$ \\
\hline & $7-8$ & $82.43 \pm 2.22$ & $83.57 \pm 2.13$ & $84.43 \pm 1.83$ & $85.14 \pm 1.23$ & 0.767 \\
\hline & $9-10$ & $84.14 \pm 1.64$ & $83.21 \pm 2.33$ & $82.29 \pm 2.04$ & $82.57 \pm 1.98$ & 0.918 \\
\hline & $11-12$ & $79.00 \pm 1.73$ & $77.86 \pm 2.09$ & $80.43 \pm 0.88$ & $79.29 \pm 1.44$ & 0.728 \\
\hline & $12-14$ & $71.29 \pm 2.16$ & $71.89 \pm 2.53$ & $71.71 \pm 1.95$ & $76.07 \pm 3.12$ & 0.495 \\
\hline & $1-14$ & $83.10 \pm 1.60$ & $82.32 \pm 1.85$ & $84.73 \pm 0.85$ & $85.01 \pm 0.87$ & 0.453 \\
\hline \multirow{8}{*}{$\begin{array}{l}\frac{+}{5} \\
\frac{0}{0} \\
3 \\
\text { o } \\
\text { Oे }\end{array}$} & $1-2$ & $62.74 \pm$ & $61.05 \pm 0.71$ & $61.17 \pm 0.42$ & $61.60 \pm 0.66$ & 0.197 \\
\hline & $3-4$ & $62.22 \mathrm{a} \pm$ & $59.63 b \pm 0.92$ & $62.06 a \pm 0.47$ & $61.54 a b \pm 0.73$ & $0.049 *$ \\
\hline & $5-6$ & $61.37 \pm$ & $59.57 \pm 0.51$ & $60.13 \pm 0.44$ & $61.41 \pm 0.71$ & 0.063 \\
\hline & $7-8$ & $60.77 \pm$ & $59.85 \pm 0.89$ & $60.31 \pm 0.52$ & $60.33 \pm 0.52$ & 0.817 \\
\hline & $9-10$ & $61.36 \pm$ & $60.06 \pm 0.45$ & $60.18 \pm 0.43$ & $61.27 \pm 0.42$ & 0.333 \\
\hline & $11-12$ & $59.70 \pm$ & $58.43 \pm 0.90$ & $58.63 \pm 0.68$ & $59.86 \pm 0.64$ & 0.536 \\
\hline & $12-14$ & $60.21 \pm$ & $58.54 \pm 0.60$ & $59.04 \pm 0.59$ & $59.52 \pm 0.76$ & 0.463 \\
\hline & $1-14$ & $62.20 \pm$ & $59.59 \pm 0.51$ & $60.36 \pm 0.28$ & $60.77 \pm 0.42$ & 0.127 \\
\hline
\end{tabular}

a,b: Means on the same line with different superscript differ significantly. $\left({ }^{*}\right): p<0.05,\left({ }^{* *}\right): p \leq 0.01,\left({ }^{* * *}\right): p<0.001, n: 10$.

The birds were housed in battery cages with automatic drinker design during the 14 wks experimental period. The temperature maintained at $20-22^{\circ} \mathrm{C}$ according to normal management practice. Chicks were maintained on a 17 hours constant light schedule until the end of the experiment.

\section{Performance analysis}

For determined to content of nutrients of diets (Table 1), feed samples were collected at start, middle and end of trial then they were analyzed (AOAC, 1990). During the experimental period, the egg production of the hens was evaluated by daily recording where 
Table 3 - Some egg quality parameters of laying hens for weekly (Mean \pm SE)

\begin{tabular}{|c|c|c|c|c|c|c|}
\hline & & & & Experiment Groups & & \\
\hline & Weeks & C (Control) & $\mathrm{H}$ (1 g/kg Humate) & BA (90 mg/kg Boric Acid) & HBA (90 ppm BA plus $1 \mathrm{~g} / \mathrm{kg} \mathrm{H}$ ) & $\mathrm{P}$ \\
\hline \multirow{8}{*}{ 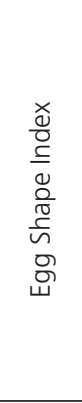 } & $1-2$ & $77.80 \pm 0.39$ & $77.78 \pm 0.59$ & $77.15 \pm 0.47$ & $78.20 \pm 0.46$ & 0.483 \\
\hline & $3-4$ & $77.88 \pm 0.43$ & $76.82 \pm 0.47$ & $77.73 \pm 0.41$ & $77.33 \pm 0.26$ & 0.253 \\
\hline & $5-6$ & $78.43 \pm 0.61$ & $77.13 \pm 0.48$ & $77.68 \pm 0.50$ & $78.43 \pm 0.41$ & 0.202 \\
\hline & $7-8$ & $77.79 \pm 0.56$ & $77.76 \pm 0.33$ & $78.38 \pm 0.44$ & $77.58 \pm 0.49$ & 0.647 \\
\hline & $9-10$ & $77.42 \pm 0.44$ & $77.45 \pm 0.66$ & $77.85 \pm 0.46$ & $77.68 \pm 0.42$ & 0.921 \\
\hline & $11-12$ & $77.64 \pm 0.34$ & $76.41 \pm 0.42$ & $76.97 \pm 0.54$ & $76.37 \pm 0.43$ & 0.157 \\
\hline & $12-14$ & $77.28 \pm 0.41$ & $76.75 \pm 0.33$ & $77.90 \pm 0.47$ & $76.80 \pm 0.63$ & 0.287 \\
\hline & $1-14$ & $77.75 \pm 0.24$ & $76.91 \pm 0.15$ & $77.67 \pm 0.22$ & $77.49 \pm 0.23$ & 0.060 \\
\hline \multirow{8}{*}{ 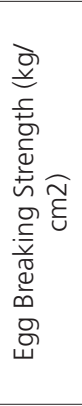 } & $1-2$ & $1.71 \pm 0.10$ & $1.90 \pm 0.11$ & $1.66 \pm 0.08$ & $1.70 \pm 0.11$ & 0.309 \\
\hline & $3-4$ & $1.71 \pm 0.13$ & $1.99 \pm 0.10$ & $1.85 \pm 0.12$ & $2.05 \pm 0.11$ & 0.185 \\
\hline & $5-6$ & $1.31 \pm 0.09$ & $1.49 \pm 0.11$ & $1.48 \pm 0.09$ & $1.45 \pm 0.07$ & 0.430 \\
\hline & $7-8$ & $1.31 \pm 0.09$ & $1.36 \pm 0.12$ & $1.36 \pm 0.08$ & $1.31 \pm 0.09$ & 0.970 \\
\hline & $9-10$ & $1.39 \pm 0.10$ & $1.43 \pm 0.09$ & $1.47 \pm 0.13$ & $1.26 \pm 0.12$ & 0.586 \\
\hline & $11-12$ & $0.91 \pm 0.11$ & $0.91 \pm 0.15$ & $1.02 \pm 0.16$ & $1.05 \pm 0.13$ & 0.844 \\
\hline & $12-14$ & $1.34 \pm 0.15$ & $1.38 \pm 0.14$ & $1.43 \pm 0.15$ & $1.43 \pm 0.14$ & 0.957 \\
\hline & $1-14$ & $1.41 \pm 0.06$ & $1.44 \pm 0.07$ & $1.45 \pm 0.05$ & $1.42 \pm 0.05$ & 0.960 \\
\hline \multirow{8}{*}{ 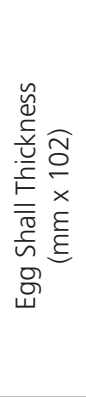 } & $1-2$ & $37.73 \pm 0.41$ & $37.73 \pm 0.45$ & $37.10 \pm 0.31$ & $37.72 \pm 0.32$ & 0.558 \\
\hline & $3-4$ & $35.07 \pm 0.41$ & $34.04 \pm 0.48$ & $34.87 \pm 0.58$ & $35.27 \pm 0.51$ & 0.332 \\
\hline & $5-6$ & $36.32 \pm 0.44$ & $35.96 \pm 0.45$ & $36.63 \pm 0.31$ & $36.11 \pm 0.45$ & 0.697 \\
\hline & $7-8$ & $34.02 \pm 0.51$ & $35.32 \pm 0.55$ & $34.17 \pm 0.56$ & $35.37 \pm 0.56$ & 0.162 \\
\hline & $9-10$ & $33.38 \pm 0.46$ & $33.17 \pm 0.47$ & $33.10 \pm 0.39$ & $34.07 \pm 0.56$ & 0.458 \\
\hline & $11-12$ & $34.17 \pm 0.63$ & $34.13 \pm 0.49$ & $33.20 \pm 0.58$ & $32.90 \pm 0.55$ & 0.288 \\
\hline & $12-14$ & $33.23 \pm 0.65$ & $34.70 \pm 0.68$ & $34.40 \pm 0.81$ & $34.87 \pm 0.81$ & 0.405 \\
\hline & $1-14$ & $35.06 \pm 0.17$ & $35.32 \pm 0.28$ & $34.75 \pm 0.28$ & $35.24 \pm 0.23$ & 0.359 \\
\hline
\end{tabular}

as feed intake recording weekly. Egg samples were collected, stored (at room temperature for one day) and weighed biweekly. Feed conversion ratio was calculated as kilograms of feed consumed per kilogram of egg produced. An additional sample of 10 eggs was randomly collected from each experimental group every 14 days to assess egg quality parameters which were shape index, breaking strength and shell thickness.

\section{Biochemical analysis}

At the end of the trial, blood samples $(5 \mathrm{~mL})$ were obtained from each one bird from every cage by the brachial vein for determine blood cholesterol level of hens. These samples were allowed to clot at room temperature for 6 hours and then they were centrifuged at $1500 \mathrm{~g}$ for 10 minutes at room temperature. Serum were carefully harvested and stored at $-20^{\circ} \mathrm{C}$ until analysis. The serum cholesterol concentrations were analyzed using commercial kits (Teco Diagnostic, 1286 Anaheim, CA 92807).

\section{Statistical analysis}

All data were analyzed by ANOVA using SPSS 11.50 program (Inc., Chicago, II, USA). Significant differences among treatment were determined using Duncan's multiple range tests (Duncan, 1955) with a 5\% level of probability.

\section{RESULTS}

The feed intake results for hens supplemented or not with boric acid (BA) and/or humate $(\mathrm{H})$ were reported in Table 2. It was observed that the addition $\mathrm{BA}$ and/or $\mathrm{H}$ into diets have not significantly affects 
on feed intake over the whole experimental period. However at 5th and 6th wks of treatment, feed intake was decreased by addition of boric acid and humate combination (HBA) $(p<0.05)$. It appeared that birds supplemented with HBA (group 4) exhibited lower feed intake results than control (6.74\%).

In present study most remarkable results were observed for feed conversion ratio parameters of hens. Addition of $\mathrm{H}$ at levels of $1 \mathrm{~g} / \mathrm{kg}$ was decreased statistically significant of feed conversion ratio (FCR) for hens while HBA were significant increased of it compare other group animals at the end of trial ( $p$ $<0.05$ ). Because of $\mathrm{H}$ addition was brought higher feed intake and less egg production at 5th and 6th of treatment, it also was showed statistically significant decreased for FCR in same treatment group (1 g/kg humate) than others $(p<0.001)$ in same weeks.

Theeggyieldand weightresultswerealsosummarized in Table 2. These parameters for performance were not significantly modified by the supplementation with boric acid and/or humate combination over the whole experimental period except during the 3rd and 4th wks: the egg weights were significantly higher in hens supplemented with BA than in birds supplemented with $\mathrm{H}$ alone $(\mathrm{p}<0.05)$. Egg production yield of hens was showed statistically significantly better results for BA and HBA groups at 5th and 6th of treatments ( $p<$ 0.05). Boric acid supplemented groups' hens presented higher percentage egg production than control or in birds supplemented with humate alone (3\% and $7 \%$ respectively). But these differences between treatment groups were disappeared at the end of trial.

At the end of trial it was observed that there were no effects of dietary additions on egg quality parameters (shell thickness, breaking strength, and shape index) compared with control (Table 3). In same way, even though HBA group showed $7.51 \%$ lower blood cholesterol levels than control this difference between groups did not showed any statistical significant important (Table 4).

\section{DISCUSSION}

Except of FCR, all other investigated parameters were showed no statistically significant differences between all groups by the end of present trial. These results are in agreement with the results of studies involving hens on supplementations of humate (Kucukersan et al., 2005; Yoruk et al., 2004) and boric acid (Qin \& Klandorf, 1991; Wilson \& Ruszler, 1996; Mizrak \& Ceylan, 2009). Mizrak \& Ceylan (2009) tried to determine different level of $B(25,50,75$ ppm) effects on laying hens. They didn't find any significant differences about performance parameters of hens (feed intake, egg production and weight, egg quality parameters) with supplementation of boric acid. Qin \& Klandorf (1991) investigated of effects of boron addition into hen diets on some performance, egg shell quality and calcium metabolism. At the end of their trial boron addition into hen diets caused reducing of egg production but had no effects on egg shell quality.

In present study feed conversion ratio was depressed by $1 \mathrm{~g} / \mathrm{kg}$ humate addition. This result was showed negative correlation with some other studies which are evaluate humate supplementation effects on broiler (Eren et al., 2000; Karaoglu et al., 2004) and laying hens (Ceylan \& Ciftci, 2003; Kucukersan et al., 2004) but showed similar results with Koksal (2009) study which was determined humate and herb extracts effects on broiler and laying hens performance and some blood and immune parameters. In that study researcher found that addition of humate at level of $1.5 \mathrm{~g} / \mathrm{kg}$ showed negative effects on FCR for hens (24 weeks old, 200 Hyline-White ${ }^{\circledR}$ 98) end of trial. The differences about results between other studies and ours can be caused by using of different composition of humate with different feed additives and different levels in different animal types.

Egg productions of hens which fed with humate and boric acid diets did not differ ( $p>0.05)$, but egg production for groups which were supplemented with boric acid (BA and HBA) showed greater egg production results than hens fed the control diet (84.73 vs. $83.10 \%$ and 85.01 vs. $83.10 \%$, respectively, Table 2). The HBA group in this trial usually showed better results compare with control and other groups but those results usually didn't get a meaning in statistically significant way (except FCR, $p<0.05$ ). This result showed positive correlation with Wilson \& Ruszler (1995) study who found out addition

Table 4 - Blood cholesterol levels of laying hens (mg/dl) (Mean \pm SE).

\begin{tabular}{|c|c|c|c|c|}
\hline \multicolumn{4}{|c|}{ Experiment Groups } & \multirow[b]{2}{*}{$p$-value } \\
\hline C (Control) & H (1 g/kg Humate) & BA (90 mg/kg Boric Acid) & HBA (90 ppm BA plus $1 \mathrm{~g} / \mathrm{kg} \mathrm{H}$ ) & \\
\hline $177.46 \pm 9.29$ & $193.81 \pm 17.42$ & $176.80 \pm 13.55$ & $165.06 \pm 14.43$ & 0.558 \\
\hline
\end{tabular}


of different levels of boron (3, 5, 7, 14, 28 and 56 ppm) into laying hen diets had showed no statistically significant difference between all treatment groups. There was no difference in feed intake of hens fed supplements (humate and boric acid or combination). However, there were numerical decrease in feed intake for hens fed humate and boric acid combination diets compared with hens fed the control diet (97.59 vs. $99.68 \mathrm{~g} /$ day per animal respectively, Table 2). Egg weight decreased numerically in parallel egg production decreased slightly as in present study by $1 \mathrm{~g} / \mathrm{kg}$ humate supplementation. Rossi et al. (1990) searched for the effect of feeding two sources of boron (boric acid and borax) on broiler breeder performance. They found that addition of different type of humate into diets did not effect of egg weights and this result has positive correlation with present trial. Although there were no significant differences in egg quality parameters in all groups (Table 3), egg breaking strength and shell thickness was numerically influenced by supplemental humate or boric acid in this trial. On the other hand Qin \& Klandorf (1991) reported that egg shell thickness was not affected by $100 \mathrm{mg} / \mathrm{kg} \mathrm{B}$ in aged broiler breeder hens. In present study addition of humate and boric acid ( $\mathrm{H}$ and $\mathrm{BA}$ groups) were brought increase egg breaking strength than control group 2.12 and $2.83 \%$, respectively. Similar result also was presented by Yesilbag \& Eren (2008). They evaluated effects of different levels of boron (25, 50 and 100 ppm) into late period of laying hens' diets on performance and egg shell quality. At the end of their trial researchers found that addition of boron had some positive effects on egg shell thickness and breaking strength.

Blood cholesterol levels showed any no statistically significant differences between all treatment groups. However addition of boric acid combination with humate (HBA) into hen diets caused numerical decrease of blood cholesterol levels compare with hens fed with control diets (165.06 vs. $177.46 \mathrm{mg} / \mathrm{dl}$ respectively). Interestingly single addition of boric acid into diets didn't change blood cholesterol levels of animals but single addition of humate caused numerical increase blood cholesterol levels of hens compare with control group (193.81 vs. $177.46 \mathrm{mg} / \mathrm{dl}$ respectively). This result showed positive correlation with Koksal (2009) who investigated to effects of humate and herb extract supplementation on broiler and laying hen diets. He found out that addition of humate into hen diets was caused slightly increase blood cholesterol levels but it didn't show statistically significant important ( $p>$ 0.05). Eren et al. (2004) investigated the influence of different levels $(0,5,10,50,100,200$ and 400 ppm) of dietary boron (B) supplementation on egg production, interior and exterior egg quality and serum parameters related to egg formation in laying hens. For this purpose two hundred and twenty four, 18 week old, Hyline Brown 98 strain hens were used. At the end of their trial they notice that addition of boron into hen diets caused increasing of cholesterol levels of egg but also resulted with decrease of blood cholesterol level. Contrary these results Kurtoglu et al. (2005) observed that addition of boron into broiler diets caused the increasing of cholesterol levels in their research.

In this study, the effects of supplementation of humate and boric acid during in the middle laying period on egg production and egg quality parameters were investigated, and their effectiveness was compared. Supplemental humate and boric acid combination had linear effects on production parameters including reduced feed intake and increased egg production. However, they had no specific effects on egg quality parameters. As a result supplemental boric acid (90 ppm) was improved some performance (feed intake, egg production) and some egg quality (egg breaking strength, shell thickness) parameters numerically and it was statistically significant effects for FCR on laying hens.

\section{ACKNOWLEDGEMENTS}

This research was supported by T.R. Prime Ministry State Planning Organization (DTP) Project No: 2003K120190.

\section{REFERENCES}

AOAC. Official methods of analysis of the association of official analytical chemists. 14th ed. Virginia; 1990.

AOAC. Official methods of analysis of the association of official analytical chemists. 17th ed. Virginia; 2000.

Ceylan N, Ciftci I, Kahraman Z, Mizrak C. Yumurta tavuğu yemlerinde humat bileşikler (Farmagülatör Dry Plus) kullanımının performans, yumurta kalitesi ve bağırsak mikroflorası üzerine etkileri. II. Ulusal Hayvan Besleme Kongresi 2003; 163-167.

Duncan DB, Multiple range and multiple F test. Biometrics 1955; 11: 1-42.

Dupre, JN, Keenan, MJ, Hegsted, M, Brudevold, AM. Effects of dietary boron in rats fed a vitamin D-deficient diet. Environ. Health Perspect 1994; 102: 55-58.

Eren M, Gezen SS, Deniz G, Turkmen II. Broyler yemlerine katılan humatların besi performansı, serum mineral konsantrasyonu ve kemik külü üzerine etkileri. Ankara Üniversitesi Veteriner Fakültesi Dergisi 2000;47: 255-263.

Eren M, Uyanık F, Kucukersan S. The influence of dietary boron supplementation on egg quality and serum calcium, inorganic 
phosphorus, magnesium levels and alkaline phosphatase activity in laying hens. Research in Veterinary Science 2004; 476: 203-210.

Ergin O, Coskun I, Ocak N, Erener G. Effects of dietary humic substances on egg production and egg shell quality of hens after peak laying period. African Journal of Biotechnology 2009; 8(6): 1155-1159.

Hayirli A, Esenbuga N, Macit M, Lacin E, Karaoglu M, Karaca H, Yildiz L. Nutrition practice to alleviate the adverse effects of stress on laying performance, metabolic profile, and egg quality in peak producing hens: I. the humate supplementation. Asian-Australian Journal of Animal Science 2005; 18: 1310-1319.

Hegsted M, Keenan MJ, Siver F, Wozniak P. Effect of boron on vitamin D deficient rats. Biological Trace Element Research 1991; 28: 243-255.

Hobbs D. Humate feeding trial; 1995. Available from: www.richearth.net/ horses.php. Accessed in: Jul 62005.

Hunt, C.D. Dietary boron modified the effects of magnesium and molybdenum on mineral metabolism in the cholecalciferoldeficient chick. Biological Trace Element Research 1989; 22: 201-220.

IPCS. Scientific Facts on Boron. Green facts, facts on health and the enverioment; 1998. Available from: www.greenfacts.org/en/boron/ boron-1.htm. Acessed in: Jan 102010.

Karaoglu M, Macit M, Esenbuga N, Durdag $H$ ve, Bilgin ÖC. Effect of dietary humate on performance, slaughter, carcass and meat quality parameters of broilers. International Journal of Poultry Science 2004; 6:406-410.

Kilic AM. Importance of Boron Mine for Turkey and Place in the Future. II Uluslararası Bor Sempozyumu, 23-25 Eylül Eskişehir Türkiye; 2008; p.31-41.

Koksal BH. Humat ile bitki ekstraktarının broyler ve yumurtacı tavuklarda kullanılması [doctorate thesis]. Istanbul: Ankara Üniversitesi Veteriner Fakültesi Hayvan Besleme ve Beslenme Hastalıkları; 2009.

Kucukersan S, Kucukersan K, Colpan I, Goncuoglu E, Reisli Z, Yesilbag D. The effects of humic acid on egg production and egg traits of laying hen. Veterinarni Medicina 2005; 50: 406-410.

Kucukersan S, Kucukersan K, Goncuoglu E, Sahin T. The effects of dietary humate supplementation on laying hen egg production and egg quality. Indian Veteterinary Journal 2003; 81: 674-678.

Kuhnert VM, Bartels KP, Kroll S, Lange N. Huminsäurehaltige tierarzneimittel in therapie and prophylaxe bei gastrointestinalen erkrankungen von hund und katze. Monatshefte fur Veterinarmedizin 1991; 46: 4-8.

Kuhnert VM, Fuchs V, Golbs S. Pharmakologish-toxikologische eigenshaften huminsäuren und ihre wirkung-sprofile für eine veterinarmedizinische therapie. Deutsche Tierärtzliche Wochenschrift 1989; 96: 3-10.

Kurtoglu F, Kurtoglu V, Celik D, Kececi T, Nizamlıglu M. Effects of dietary boron supplementation on some biochemical parameters, peripheral blood lymphocyte, splenic plasma cell, counts and bone characteristics of broiler chicks fed with adequate or in adequate vitamin $d 3$ containing diet. Bristih Poultry Science 2005; 46: 87-96.

Kurtoglu V, Coskun B, Seker E, Balevi T, Cetingul IS. Effects of boron supplementation on performance and some serum biochemical parameters in laying hens. Revue de Médecine Vétérinaire 2002; 153: 823-828.

Mizrak C, Ceylan N. Damızlık yumurta tavuğu yemlerine farklı seviye ve formda bor ilavesinin performans, kemik gelişimi ve bazı kan parametreleri üzerine etkisi, V. Ulusal Hayvan Besleme Kongresi 2009; 130-138.
National Research Council. Nutrient requirements for poultry. 9th Washington: National Academy Press; 1994. p.26-34.

NIST. National Institute of Standards and Technology. 21]. Available from: http://physics.nist.gov/cgi-bin/Compositions/stand_alone.pl

Nys Y. Nutritional factors affecting eggshell quality. Czech Journal of Animal Science 1999; 44: 135-143.

Qin $\mathrm{X}$, Klandorf $\mathrm{H}$. Effects of dietary boron supplementation on egg production, shell quality, and calcium metabolism in aged broiler breeder hens. Poultry Science 1991; 70: 2131-2138.

Rossi AF, Bootwalla SM, Miles RD. The effect of feeding two sources of boron on broiler breeder performance. Poultry Science 1990; 69: 187.

WHO. World Health Organization. International programme on chemical safety. Boron: Environmental Health Criteria; 1998. p.1-201.

WHO. World Health Organization. Trace elements in human nutrition and health. Geneva, 1996; 175-182.

Wilson JH, Ruszler PL. Effects of dietary boron on poultry bone. Strength. Transactions of the ASAE 1995; 38: 167-170.

Wilson JH, Ruszler PL. Long term effects of boron on layer bone strength and production parameters. British Poultry Science 1998; 39: 11-15.

Yalcin S, Ergun A, Erol H, Yalcin S, Ozsoy B. Bıldırcın Yemlerinde L-Karnitin ve Humat Kullanımının Performans, Yumurta Kalitesi ve Bazı Kan Parametreleri Üzerine Etkileri. III. Ulusal Hayvan Besleme Kongresi; 2005. p.227-233.

Yesilbag D, Eren M. Effects of Dietary Boric Acid Supplementation on Performance, Eggshell Quality and Some Serum Parameters in Aged Laying Hens. Turkish Journal of Veterinary and Animal Science 2008; 32(2): 113-119.

Yildiz G, Ozcelik F, Koksal BH, Bagder S, Abacioglu O. Organik Bor Üretilebilirliği ve Broyler Rasyonlarında Bor ile Humatın Kullanımı. II. Ulusal Bor Çalıştayı Bildiri Kitabı; 2008. p.597-604.

Yoruk MA, Gul M, Hayirli A, Macit M. The effetcs of supplementation of humate and probiotic on egg production and quality parameters during the late laying period in hens. Poultry Science 2004; 83: 84-88 
